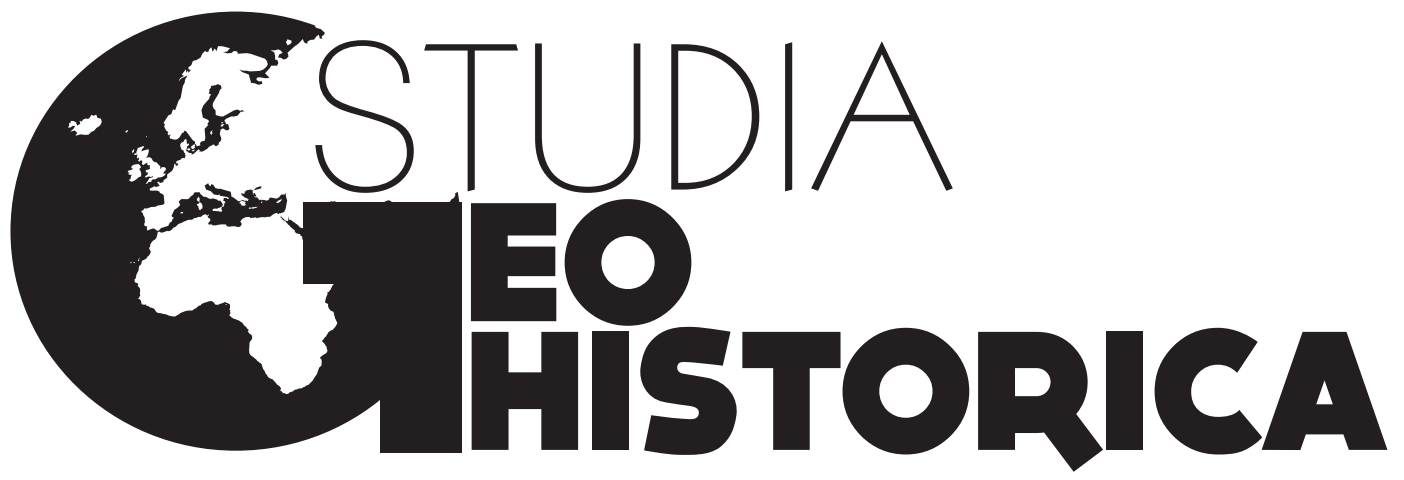

NR 06|2018 ROCZNIK HISTORYCZNO-GEOGRAFICZNY 


\section{Contents}

A note from the editors 5

International Conference of Historical Geographers

Diogo de Carvalho Cabral

Landscape and Letterscape in Early Colonial Brazil 7

Karen M. Morin

Prisoners and Animals: An Historical Carceral Geography ... 28

Humphrey Southall

Spaces, Places, Features and Units: Web-Enabling Historical Geography. 39

\section{Articles and theses}

Agnieszka Latocha, Dominik Nowakowski

Sources and Methods Used in the Reconstruction of Settlement Networks:

An Archaeological and Geographical Perspective on the Example of Silesia

Marek Sobczyński

Polish Geographical Survey of Borders until 1945

\section{Roman Czaja}

Historical Atlas of Polish Towns. Between Source Edition

and the Cartographic Presentation of Research on the History of Towns

\section{Piotr Guzowski}

Economic Geography of Poland in the Period of Growth (14-16th Century)

in the Polish Historical Study

Dzmitry Vitsko

Historical Cartography in Belarus (Studies on the Administrative Division,

Borders and Population of the Grand Duchy of Lithuania)

Henryk Rutkowski

A Few Comments on the Historical Borders in Poland

Bogumił Szady

Historical Cartography of Confessions and Religions in the Polish-Lithuanian

Commonwealth: Between Historical Geography and Spatial History 136 


\section{Tomasz Figlus}

The Past and Present of Historical Morphology of Rural and Urban Forms in Poland

\section{Maryana Dolynska}

Some Principles of Interdisciplinary Investigation

for Recreating the Historical Topography of Urban Spaces

\section{Atlas Fontium}

Atlas Fontium

(Marek Stoń)

Tomasz Panecki, Tomasz Związek, Grzegorz Myrda

The Spatial Database Development for Research on Settlements and Afforestation in Nowy Tomyśl Plain in Early Modern Times

Marek Słoń, Urszula Zachara-Związek (eds.)

The Court Records of Wschowa (1495-1526). Digital Edition

\section{Reviews and discussions}

Deutscher Historischer Städteatlas, Nr. 5: Dortmund, Hrsg. Peter Johanek, Jürgen Lafrenz, Thomas Tippach, Münster 2018 (Michał Stomski) 


\title{
Sources and Methods Used in the Reconstruction of Settlement Networks: An Archaeological and Geographical Perspective on the Example of Silesia
}

\author{
Agnieszka Latocha, Dominik Nowakowski
}

Research on settlement history is one of the more interesting branches of historical scholarship. Objectively speaking, the study of settlement processes is rendered difficult by the complexities of its methodology, a problem which stems from a large number and variety of its sources. However, the same multitude and diversity of sources available is also what draws the interest of researchers from across many fields, prominently archaeologists, historians, and historical geographers and while these fields of research are complementary to one another, they all have their own established research methods.

In Herbert Jankuhn's classical approach, stating that the material evidence of human activity in a given area consists of burials, settlements, traces of agricultural activity, places and traces of fortifications and fortified settlements, places of worship and sacrificial sites, as well as hoards; maps of various sites and findings constructed by means of search queries, can also constitute viable sources of information ${ }^{1}$. Furthermore, the rich character of the term settlement archaeology was best described by Leszek Kajzer, for whom everything that is a subject to archaeological interest is a remnant of a settlement process. This includes singular objects, such as buildings with different purposes: religious (churches and churchyards, monasteries, hospitals), lay (castles, manors, city architecture, and country homes), as well as ones significant for the history of industry and production (e.g.: brickyards,

H. Jankuhn, Einführung in die Siedlungsarchäologie, Berlin-New York 1977, p. 18-21. smithies, foundries). All of the above are usually a part of a larger whole that forms the settlement complex of an urban or rural character ${ }^{2}$.

The broad spectrum of research within settlement archaeology has caused it to develop narrower, specialised fields, the aim of which is to study the particular types of sites and objects - religious centres, castles, cities, and villages - among which there would also be settlements considered lost. A separate, but an equally important, matter is desk study on material culture, as movable historical objects are still the staple for chronological dating, which is why works of typo-chronological character remain particularly relevant ${ }^{3}$.

Studies on mediaeval settlement are placed in a broader context of the so-called historical archaeology, which includes not only material sources from excavations, but also from written accounts, cartographic sources, and remnanats of older cultural landscapes. Thus integrated, interdisciplinary cooperation by researchers representing multiple fields of interest is the optimal method for researching this complex matter.

Within the scope of the aforementioned categories of sources enabling the analysis of the earliest settlement processes are archaeological materials, which can both deliver the basic information on Early Medieval settlement processes and provide insight into settlement in the Late Middle Ages to the level other sources (such as written accounts) can

2 L. Kajzer, Wstęp do archeologii historycznej w Polsce, tódź 1996, p. 156. 3 Ibidem, p. 206. 
hardly reach. Examples of key subjects pertaining to Central European history for which archaeological sources remain crucial are the emergence of states in the $10^{\text {th }}$ century $\mathrm{CE}$, and the later rise and development of $13^{\text {th }}$-century settled colonies established by Germans and/or on the basis of German law. The research done on the former, where the most progress has been made for the region of Greater Poland, has provided knowledge on the role of the network of strongholds (Pol. gród, Pol. grody) - strategically and religiously central to the local communities and located in key regions - played in the shaping and development of Poland state ${ }^{4}$. An equally recognisable phenomenon (e.g.: in south-west Greater Poland and in Silesia) is the disappearance of numerous minor fortified settlements dating back to tribal times, which were then replaced by less populated, but larger early Piast dynasty strongholds 5 . The turn of the $13^{\text {th }}$ century brought the archaeologically well-researched process of settlement concentration (Ger. Ballungsprozes, Ballungsvorgang), observed in the regions in which Early Medieval settlement had been well-developed. The process entailed the establishment of one major founding village with a distinct land ownership structure, consistent spatial organisation, and a structured field plan ${ }^{6}$. Similar changes have been noted in the case of municipal towns founded on the basis of Early Medieval polycentric settlement complexes ${ }^{7}$. In both cases, the previous

4 M. Kara, Najstarsze państwo Piastów - rezultat przełomu czy kontynuacji. Studium archeologiczne, Poznań 2009.

5 S. Moździoch, Organizacja gospodarcza państwa wczesnopiastowskiego na Śląsku. Studium archeologiczne, Wrocław-Warszawa-Kraków 1990, p. 46-48.

6 H.K. Schulze, Die Besiedlung der Mark Brandenburg im hohen und späten Mittelalter, "Jahrbuch für die Geschichte Mittel- und Ostdeutschland", 28, 1979, p. 42-178; E. Gringmuth-Dallmer, Landesausbau und Wüstungsgeschehen, in: Mensch und Umwelt. Studien zu iedlungsausgriff und Landesausbau in Ur- und Frühgeschichte, Hrsg. H. Brachmann, H.-J. Vogt, Berlin 1992, p. 209-217.

7 J. Piekalski, Od Kolonii do Krakowa. Przemiana topografii wczesnych miast, Wrocław 1999. settlements in the area had deteriorated as a result of the development of Late Medieval and modern structures.

Scholarly interest in the history of Poland after 1945 was a reflection of the contemporary goals set for archaeological work as the country approached its $1000^{\text {th }}$ year of existence, the excavations focused on the more important strongholds and early urban centres of Poland in the Piast period $^{8}$. Likewise, rural settlements of the Early Middle Ages also enjoyed particular attention at the time. This trend resulted in two major approaches to research (utilised chiefly in the 1960s and 1970s), differentiating in their spatial range and source base, and, subsequently, their aims and methodology. The first was a multi-pronged approach focused on the identification of settlement complexes functioning within geographical micro- and macroregions, making use of various sources (archaeological, written, cartographic) to follow the Early Medieval settlement patterns within the frame of microregions (dwellings concentrated around strongholds, monastic properties, parishes), giving a only a modicum of attention to the changes occurring within the settlements themselves. The second approach, employed much more widely, focused on individual sites (habitats) with the use of excavations. It was limited to identifying the spatial plans of settlements, the structural types present at the sites, as well as the functional variety of buildings and utilities found in a given area. This approach allowed for better exploration of singular settlements, but neglected the broader context of settlement processes? .

\footnotetext{
8 L. Kajzer, Wstęp, p. 14.

9 M. Młynarska-Kaletynowa, W sprawie polskich badań nad osadnictwem średniowiecznym, "Studia z Dziejów Osadnictwa", 6, 1968, p. 82-102; J. Kolenda, Dawne projekty - nowe możliwości. Przyczynek do badań wczesnośredniowiecznej wsi, in: Cum gratia et amicitia. Studia z dziejów osadnictwa dedykowane Pani Profesor Marcie Mlynarskiej-Kaletynowej z okazji 65-lecia działalności naukowej, red. D. Adamska, K. Chrzan, A. Pankiewicz, Wrocław 2017, p. 45-47.
} 
There was a significant drop in interest in rural settlements among Polish archaeologists in the last few decades, the decline largely driven by the state's efforts to revitalise the country after the systemic changes following the fall of communism in 1989. Polish archaeologists were engaged in rescue restoration focusing primarily on towns that had been neglected for decades; however, the subject of rural settlement has seen renewed interest in the recent years and new research endeavours have since been launched. A significant number of researchers, including those from younger generations, have concentrated on studying settlement processes emerging as a result of the $13^{\text {th }}$-century colonies established by Germans and/or on the basis of Magdeburg rights. These studies have utilised methods stemming from neighbouring countries, where the state of research on Late Medieval rural settlement is much more advanced ${ }^{10}$. Historical archaeology requires these research endeavours to employ the widest possible array of sources - archaeological, written, onomastic, cartographic, iconographic, and, made available in the recent years, ALS and LiDAR laser scanning data. The initiatives are most often interdisciplinary endeavours (a trend mirrored in the numerous articles and monographs ${ }^{11}$ that have been published in recent years) and, to a lesser degree, coordinated projects employing representatives of different fields of expertise; a study aimed at creating a dictionary of medieval villages in Silesia, employing archaeologists, historians, a geographer, and a cartographer, conducted a few years ago might

\footnotetext{
${ }^{10} \mathrm{~A}$ good example is the work done in eastern Germany from the 1960 s to 1980 s by research group Germania Slavica, whose members represented various scholarly fields, including archaeologists, historians, geographers, and linguists.

11 K. Fokt, Późnośredniowieczne osadnictwo wiejskie na Dolnym Śląsku wświetle badań archeologicznych, Kraków 2012; M. Legut-Pintal, Śląski model melioratio terrae na przykładzie ziemi nysko-otmuchowskiej i Pogórza Kaczawskiego, in: Cum gratia et amicitia, p. 179-194.
}

serve here as an example of one such project $^{12}$.

Compared to Poland's neighbouring regions (Bohemia, Moravia, and Germany) archaeological studies on Late Medieval rural settlement in Silesia are not well-developed. A monograph released a few years ago summed up the state of research in the field, with the majority of the data seemingly to have come from old filed surveys, with excavations (mostly rescue efforts) being more rare; methodical research, employing surface verification and excavations, being a notable exception ${ }^{13}$. An aerial surface identification project conducted on a broad scale was launched in the 1970s and 1980s as part of the Archaeological Survey of Poland (Archeologiczne Zdjęcie Polski) initiative; in some regions, the initiative has even been continued to this day. However, from the perspective of medieval settlement research, the usefulness of the data procured by such means is limited. The reason for that is the lack of precision in chronological dating of archaeological sites, which does not allow for the reconstruction of the dynamics of settlement processes ${ }^{14}$; better results in are often achieved solely by charting medieval sites within the borders of villages. Such chartings have been attempted during the work on the first volume of the dictionary of medieval villages in Silesia and observations made on dozens of villages helped establish the aforementioned process of settlement concentration, a consequence of establishing villages on the basis of Magdeburg rights (fig. 1). Most Late Medieval artefacts (mostly fragments of ceramics) have been discovered in close proximity to the

\footnotetext{
12 Stownik wsiśląskich w średniowieczu, t. 1: Powiat lubiński, oprac. D. Adamska et al., Wrocław 2014.

13 K. Fokt, Późnośredniowieczne osadnictwo, p. 71-109.

${ }^{14}$ S. Moździoch, Refleksje na temat stanu wiedzy archeologicznej o śląskim wczesnym średniowieczu, in: Stan i potrzeby badań nad wczesnym średniowieczem w Polsce - 15 lat później, red. W. Chudziak, S. Moździoch, Toruń-Wrocław-Warszawa 2006, p. 192-200; K. Fokt, Późnośredniowieczne osadnictwo, p. 80.
} 


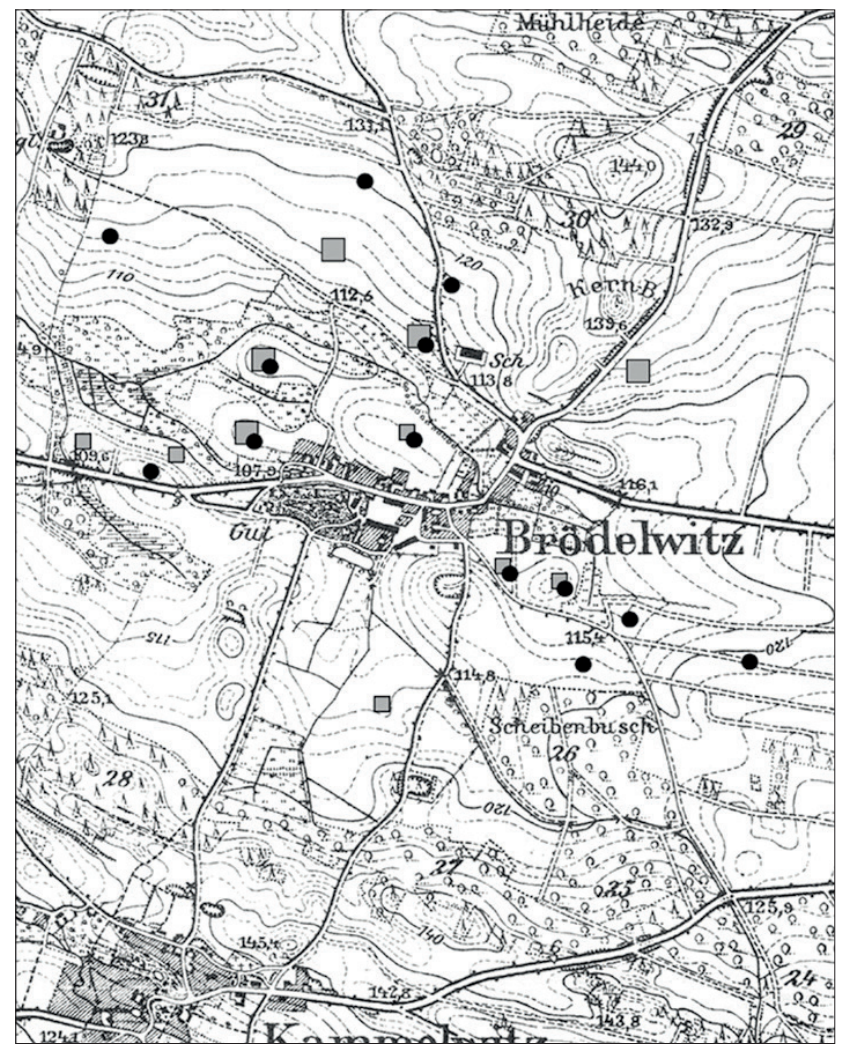

Fig. 1. Brodowice village, Lubin district, with the location of Early Medieval (grey squares) and Late Medieval (black circles) sites.

Source: D. Nowakowski's own elaboration

dwellings, where garden plots, fertilised with manure, would have been located. Charting Late Medieval archaeological sites from the area around the village of Lisiec helped establish a link between the two settlements that the village consists of - Fuhsmühl (Lisiec) and Lindhardt. Archaeological sites from the Middle Ages are only present in Lindhardt (fig. 2), which is confirmed by written accounts stating that the village of Lisiec was only established in the modern age (before $1612)^{15}$.

Field work in archaeology is very often determined by information found in written accounts. The primary aim of studies motivated by such findings is particular

15 Stownik wsi, p. 13, 61-63, 121. structures and settlements' identification in the area, followed with their further identification on the basis of the written sources a model example here is the effort to find the location of castle fortifications (unknown as late as the 1970s) in Bytom Odrzański and conduct excavations on the site $^{16}$. Similar approach was employed in the two decades between the two world wars and in recent, continuing studies on the subject of lost rural settlements ${ }^{17}$.

For research on settlement processes, written accounts play a key role in

16 S. Moździoch, Castrum munitissimum Bytom. Dzieje lokalnego grodu jako archeologiczny przyczynek do badań nad początkami państwa polskiego, Warszawa 2002

17 D. Adamska, D. Nowakowski, Bankau pod Gtogowem - zaginiona wieś w świetle źródef archeologicznych i pisanych, in: Z badań nad historią Śląska i Europy w wiekach średnich, red. M. Goliński, S. Rosik, Wrocław 2013 (Scripta Historica Medievalia, 3), p. 123-139; K. Fokt, M. Legut- 


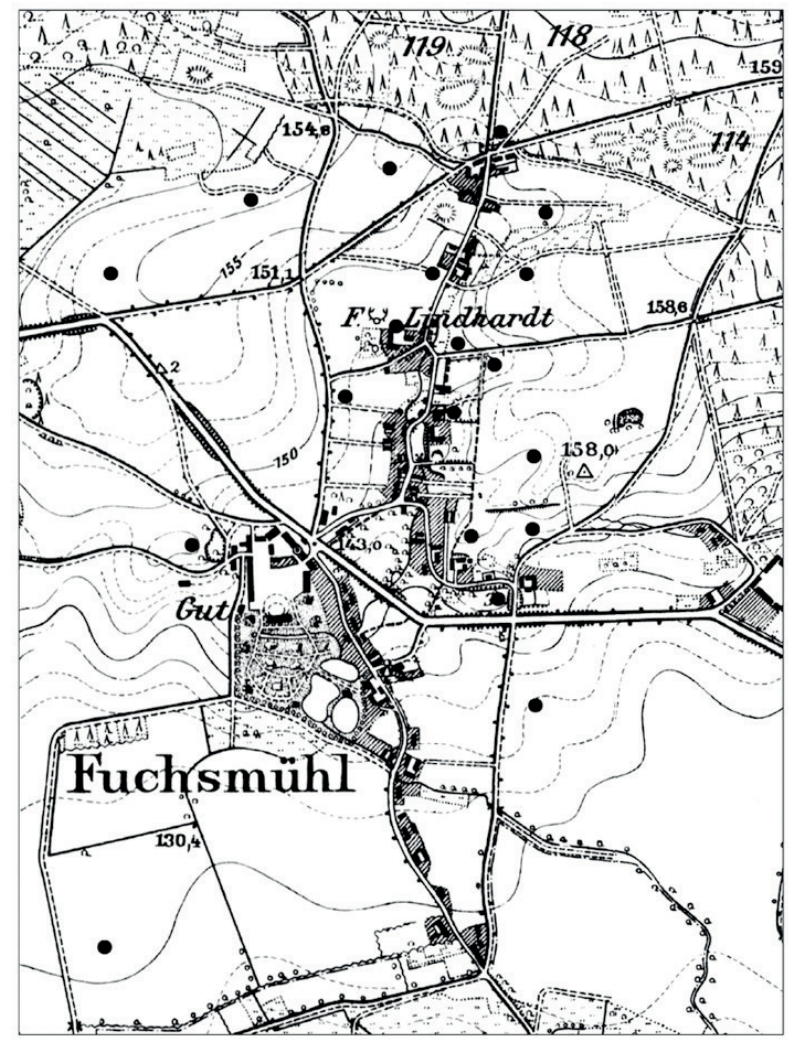

Fig. 2. Lisiec village (formerly Fuchsmühl and Lindhardt), Lubin district, with the location of Late Medieval sites.

Source: "Stownik wsi śląskich", t. 1, p. 13, fig. 2

establishing several important aspects, such as chronology, identification of settlement organizers, the analysis of land ownership and its structure, or the spatial reach of a given stronghold, town, or parish. Aside from singular documents (e.g.: charters), mass documentation compiled within a singular time period (such as land books, stock surveys, and inventory ledgers) remains an important source of statistics, providing means for comparative analysis; a land survey compiled for the bishop of Wrocław (Breslau) ${ }^{18}$ proved to be an especially valuable source on

-Pintal, Zanikłe wsie Wzgórz Strzelińskich: stan i perspektywy badań, in: Wieś zaginiona. Stan i perspektywy badań, red. P. Nocuń, A. Przybyła-Dunin, K. Fokt, Chorzów 2016, p. 113-145.

18 Liber fundationis Episcopatus Vratislaviensis, Hrsg. H. Markgraf, J.W. Schulte, Breslau 1889 (Codex Dipolmaticus Silesiae, 14).
Silesian Province during the fragmentation period at the turn of the $13^{\text {th }}$ century. Similar mass documentations that were compiled at different time periods allow for the observation of the dynamics of the Late Medieval settling processes, while Early Modern sources help with research on lost villages.

In cases of archaeologically poorly-explored regions, (rather rare) iconographic and cartographic sources are of great importance for medieval settlement research in matters encompassing, but not limited to, forms and staples of economy in the Late Medieval Polish village. They are at the same time the main source of information on the geographical aspects of medieval settlement. Historical geography, though it dates back to the $16^{\text {th }}$ 
century, would not establish its aims, methods, and core assumptions until the second half of the $19^{\text {th }}$ century; the classical approach to historical geography entails the reconstruction of the former natural landscape, the anthropogenic changes in the landscape, and the interactions between the environment and humans factored by historical and political circumstances ${ }^{19}$. Such reconstructions are possible with the use of various retrogressive methods, first of which attempts to recreate the elements of the natural landscape, while the second - anthropogenic elements in form of settlements and economy. The basis for retrogressive methods is the assumption that we can make judgements about reality in its earlier form on the basis of sources from a later period. This can be inferred on the basis of the knowledge we have of certain patterns typical for a given region. The state of a region at a later time period serves here as the key to the reconstruction of past states by means of the gradual elimination of newer layers to the eventual arrival at the original state of the region ${ }^{20}$. The limitation for using these retrogressive methods for the analysis of medieval and Early Modern settlement processes were the changes in spatial structure of settlements implemented on a grand scale at the beginning of the $19^{\text {th }}$ century, a result of intense socio-economic transformation of the rural areas in the wake of, among other factors, the abolition of serfdom and rapid industrialisation, which was also the case in many rural regions in Silesia at the time ${ }^{21}$.

The regressive method allows for the assumption that some basic features of natural landscape which influenced the development of settlement and economy,

\footnotetext{
19 J. Tyszkiewicz, Geografia historyczna Polski w średniowieczu, Warszawa 2003, p. $7-19$

20 T. Figlus, Wybrane aspekty zastosowania wielkoskalowych źródeł kartograficznych w badaniach morfogenetycznych wsi, "Biblioteka Polskiego Przeglądu Kartograficznego", 3, 2012, p. 91-103.

21 For more, see: H.Z. Szulc, Morfogeneza osiedli wiejskich w Polsce, Wrocław 1995 (Prace Geograficzne, 163).
}

such as the natural topography and soil composition, remained stable over several centuries or their transformation was limited (in case of plains and areas with no prominent landforms), or that, in areas prone to transformation (mountainous areas subject to more intensive geomorphic processes and hazard), the extent of the transformation can be estimated. This remains consistent with the notions of actualism employed in Earth sciences, stating that "the present is the key to the past," or that contemporary environmental processes allow for the replication of processes that have occurred in the past, as their underlying mechanisms have not changed $^{22}$. Consequently, this enables the description of the environment of medieval villages with the use of modern sources, especially that the particularly useful palaeoenvironmental analyses (palynological, sedimentological) are usually conducted in small areas and remain very costly. Past landforms and soil on plains or low hill lands can be considered comparable to their current state, which is an assumption supported on two pieces of evidence: low occurrence of geomorphological processes that could factor the change in terrain ${ }^{23}$, and a long time period necessary for the development of a full morphological profile of the soil ${ }^{24}$. Mountainous areas present a much harder task in recreating the natural landscape from before human migration to the area, as the intensity of erosion, exacerbated by human activity in historical times (forest clearance, tillage on slopes, networks of unreinforced roads, etc.), as well as attempts at delaying erosion might have led to local slope profile changes and changes in the terrain (settlement terraces, agricultural terraces, roadside cliffs and gullies, embankments, canals

\footnotetext{
22 J. Flis, Terminy geograficzne, Warszawa 1999.

23 Cf. Wspótczesne przemiany rzeźby Polski, red. L. Starkel et al., Kraków 2008.

24 L. Starkel, Paleogeografia holocenu, Warszawa 1977.
} 
and levees, tunnels, etc. $)^{25}$. The formation of the soils, such as colluvium at the feet of the slopes and alluvium within floodplains followed the gradual erosion of terrain ${ }^{26}$, the two processes being directly proportional to the intensity of economic activity in a given area, which needs to be taken into account in the reconstruction of the earliest settlements and their original environmental circumstances.

The natural hydrographic network, which was a strong factor for settlement, needs to be reconstructed with the awareness of both natural changes occurring in riverbed $s^{27}$ as well as artificial changes caused by channel regulation and construction of hydrotechnical objects. The transformation work had its peak in the $19^{\text {th }}$ century and the beginning of the $20^{\text {th }}$ century ${ }^{28}$, thus earlier cartographic sources (e.g.: Regler's maps from the second half of the $18^{\text {th }}$ century) can be treated as representing the state similar to that of the one present in the Middle Ages and the Early Modern period.

Another regressive method used in the reconstruction of medieval settlement processes was the retrograde record method, widely used in German research on the analysis of village structure transformation (Ger. Dorfkernforschung) ${ }^{29}$. The method entails the comparison of carto-

25 A. Latocha, Śladami przeszłości - czytanie krajobrazu kulturowego Ziemi Kłodzkiej, in: Krajobraz jako nośnik idei. Ujęcia analityczne, red. K. Kołodziejczyk, D. Chylińska, A. Zaręba, Wrocław 2014 (Studia Krajobrazowe, 4B), p. 159-172.

26 A. Teisseyre, Mady rzek sudeckich. Część l: Ogólna charakterystyka środowiskowa (na przykładzie zlewni górnego Bobru), "Geologia Sudetica", 20 (1), 1985, p. 113-195; A. Latocha, Przemiany środowiska przyrodniczego w Sudetach Wschodnich w warunkach antropopresji, Wroctaw 2007 (Studia Geograficzne, 80).

27 S. Bartosiewicz, Istniejąca i projektowana zabudowa hydrotechniczna Odry - rys historyczny, in: Korytarz ekologiczny doliny Odry, red. W. Janowski, K. Świerkosz, Warszawa 1995, p. 67-70.

28 M. Sobik, M. Kasprzak, Przyrodnicze uwarunkowania klęsk elementarnych na obszarze Dolnego Śląska, in: Klęski żywiołowe w postaci zdarzeń powodziowych i ich pochodnych na Śląsku od XIV do XX w., red. E. Kościk, B. Konopska, Warszawa 2016, p. 29-62.

29 For example: A. Krenzlin, Siedlungsformen und Siedlungsstrukturen in deutsch-slawischen Kontaktzonen (mit besonderer Berücksichtigung Brandenburgs und angrenzender Gebiete), "Germania Slavica", 1, 1980, p. 239-274. graphic sources, usually from a much later period, with material sources (written and archaeological) pertaining to the period under scrutiny. This allows for elimination of newer changes and layers and the simultaneous reconstruction of the original spatial layout of a rural settlement and its field grid. The information acquired from source documentations help in placing the range, size, and/or the location of individual elements (dwellings and places of economic activity) on a map or plan of the spatial layout of a singular settlement ${ }^{30}$. However, this method is not foolproof; for example, the lack of written sources mentioning the existence of a mill do not necessarily mean that the mill had never existed, but rather that the written sources have not survived to our day. Moreover, direct translation of material sources to later cartographic information is not always possible. Despite these problems, retrogressive methods remain fundamental for identifying old settlement structures and allow for the most precise estimation possible of their original state from several centuries past.

The most problematic element of the economic landscape to recreate are indisputably forests and ponds. Written sources mentioning forests usually do not provide a precise location, with mentions of the size and range of forests being few and far between. It might seem probable that the extent of forests in the Late Middle Ages corresponds to that of Regler's map's from the second half of the $18^{\text {th }}$ century (to the scale of $1: 24000$ ), as the main phase of the grubbing of the forest areas in Silesia mostly took place in the $13^{\text {th }}$ century and the first half of the $14^{\text {th }}$ century, reflecting the colonial settlement process. On the other hand, ponds present an unstable element, often being only temporary features or used periodically, interchangeably as fields or pastures,

30 T. Figlus, Wybrane aspekty, p. 91-103. 
which means their number and size might have changed even within a single annual cycle. In the Middle Ages and in the Early Modern period, ponds in Silesia were far more numerous than they currently are, which can be attributed to their consistent decline in the later time periods due to economic transformation, increased agricultural intensity, as well the habitat sprawl and industrial expansion in the $19^{\text {th }}$ century $^{31}$.

The earliest cartographic sources used in the geographical and colonial analysis in the context of Silesian settlement are Prussian military topographical maps, roughly to the scale of 1:24000, made under the supervision of Ludwig Wilhelm Regler between 1764 and 1770. The maps provide vertical projection data on the location of settlements, roads, bodies of water (watercourses and reservoirs), land cover differentiating meadows, thickets, riparian woodland, farmland, and land formations marked with hatchings (fig. 3 $\&$ fig. 4). Symbols were used to mark objects such as churches, residences and other structures that can be used to differentiate manors (Pol. folwark) from village areas, as well as water- and windmills. A separate body of map content is the toponymy in the form of names for villages, locations, dwellings, folwarks, mills, some elevations, and sporadic folk or local names ${ }^{32}$. However, Regler's manuscript map is not cartometric and cannot be used for quantitative measurement of phenomena and objects, as its accuracy is locally distorted, providing greater detail to open land and dwellings than to woodland. Urmesstischblätter maps, which are cartometric in comparison, were elaborated in the first half of the $19^{\text {th }}$ century in a similar scale to Regler's map (1:25 000)

31 Gospodarka stawowa na Dolnym Śląsku w świetle materiatów zachowanych $w$ archiwach państwowych we Wrocławiu i w Legnicy 14471943, red. A. Drabiński, M. Janowski, Wrocław 1980.

32 A. Konias, Kartografia topograficzna państwa i zaboru pruskiego od II połowy XVIII wieku do połowy XX wieku, Słupsk 2010, p. 90-92. and contain similar information, though depicted more clearly, with a clearer use of hatchings, colours, and markings, among other things providing an overview on the specific use of farmland (fig. 5 $\&$ fig. 6). The usefulness of these maps in research on medieval settlement processes stems from the fact that they were compiled before the greatest anthropogenic transformations of rural dwellings and surrounding areas in the subsequent period, including land amelioration, railway construction, creation of parkland and industrial areas ${ }^{33}$. The most accurate topographical maps, providing the greatest amount of detail, are the so-called Messtischblätter (1:25 000), which were being drawn for Silesia in the second half of the $19^{\text {th }}$ century. They are particularly useful in tracking the most recent settlement processes, especially in comparative analysis of shifts in settlement networks and changes in use of land, both of which were prominent in Silesia in the $20^{\text {th }}$ century. The changes stemmed from intense depopulation, driven by multiple interconnected environmental, economical, social, and political factors. The analysis of these processes and their consequences was one of the leading trends in research on settlement geography led by the research centre in Wrocław, from the 1970 s to the $1990 \mathrm{~s}^{34}$. The trend has recently seen a revival, as the new generation of researchers is taking interest in

\footnotetext{
33 Ibidem, p. 173-190.

34 Among others: S. Ciok, Rozwój osadnictwa na Dolnym Śląsku po II wojnie światowej. Tendencje i kierunki zmian, Wrocław 1994 (Acta Universitatis Wratislaviensis. Studia Geograficzne, 61), p. 9-49; idem, Zmiany ludnościowe i osadnicze w Sudetach, Wrocław 1995 (Acta Universitatis Wratislaviensis. Prace Instytutu Geograficznego. Seria B, 12), p. 51-64; B. Miszewska, Zmiany zaludnienia Sudetów w okresie powojennym, "Czasopismo Geograficzne", 60 (2), 1989, p. 135-145. W. Plewniak, Zmiany w środowisku geograficznym doliny Dzikiej Orlicy w Górach Bystrzyckich wywołane wyludnianiem wsi, Wrocław 1978 (Acta Universitatis Wratislaviensis. Prace Instytutu Geograficznego. Seria B, 2), p. 97-109; B. Sawicka, Zmiany w zaludnieniu i użytkowaniu gruntów wsi górskich na wybranych obszarach przygranicznych Sudetów Kłodzkich, Wrocław 1983 (Acta Universitatis Wratislaviensis. Studia Geograficzne, 32), p. 23-30; A. Zagożdżon, Wybrane problemy ludnościowe Sudetów na tle rozwoju regionalnego, Warszawa 1990 (Studia KPZK, 96), p. 95-111.
} 


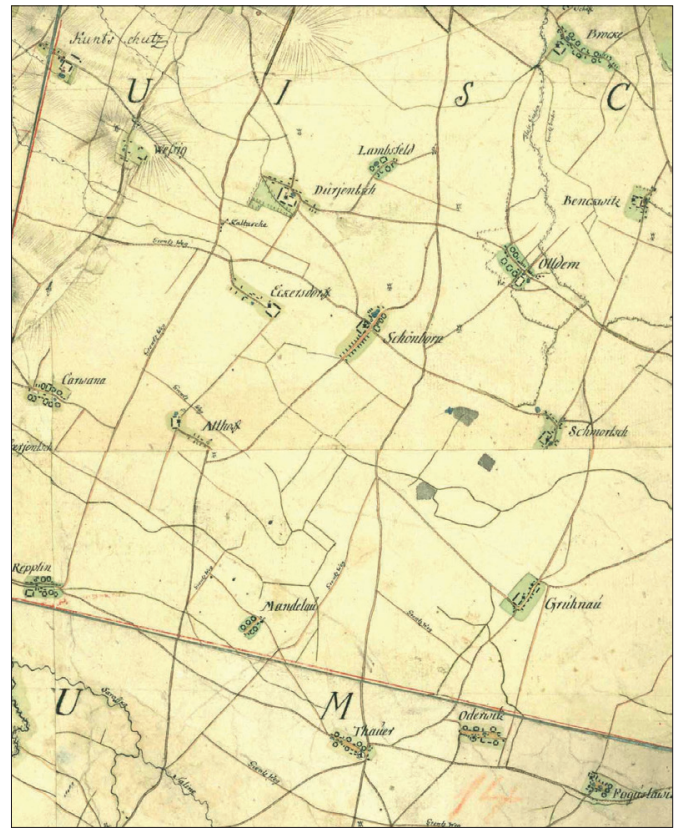

Fig. 3. A fragment of the so-called old settlement area to the south of Wroctaw according to the Regler map (1764-1770), with minor linear and manor-adjacent villages with Slavic names. Source: Staatsbibliothek Berlin, Preußischer Kulturbesitz, sign. N 15140

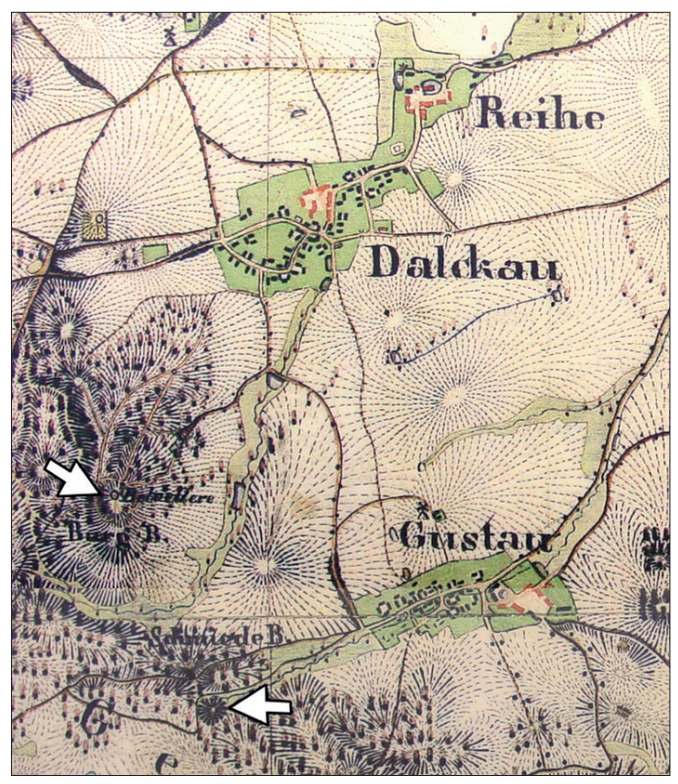

Fig. 5. The surroundings of Dalków and Gostyń villages, Polkowice county, according to the Urmeßtischblatt no. 2483 map, with the remains of Early Medieval strongholds marked. Source: Staatsbibliothek Berlin, Preußischer Kulturbesitz, sign. $N 729$

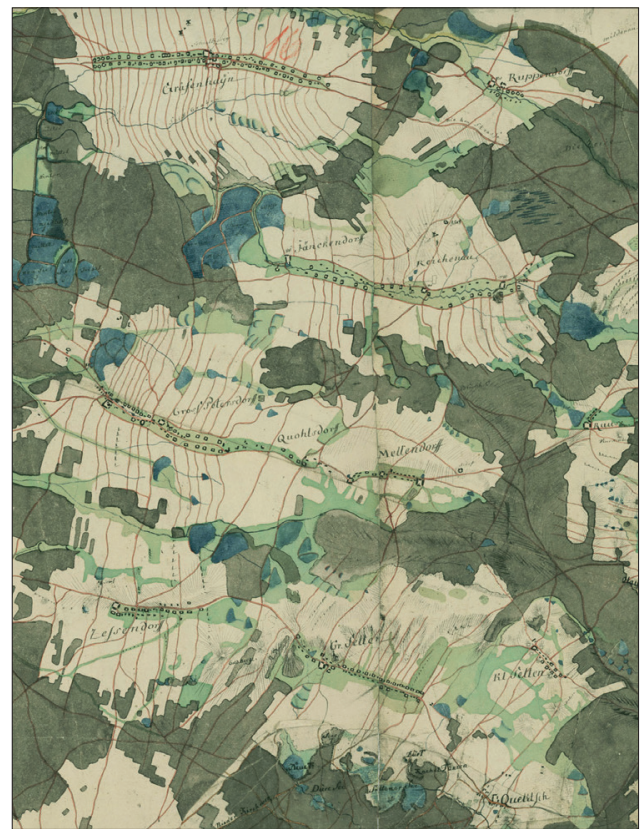

Fig. 4. A fragment of the Silesian-Lusatian woodland border according to the Regler map (1764-1770), with major colonial villages with Waldhufendorf ('forest') villages and German names. Source: Staatsbibliothek Berlin, Preußischer Kulturbesitz, sign. N 15140

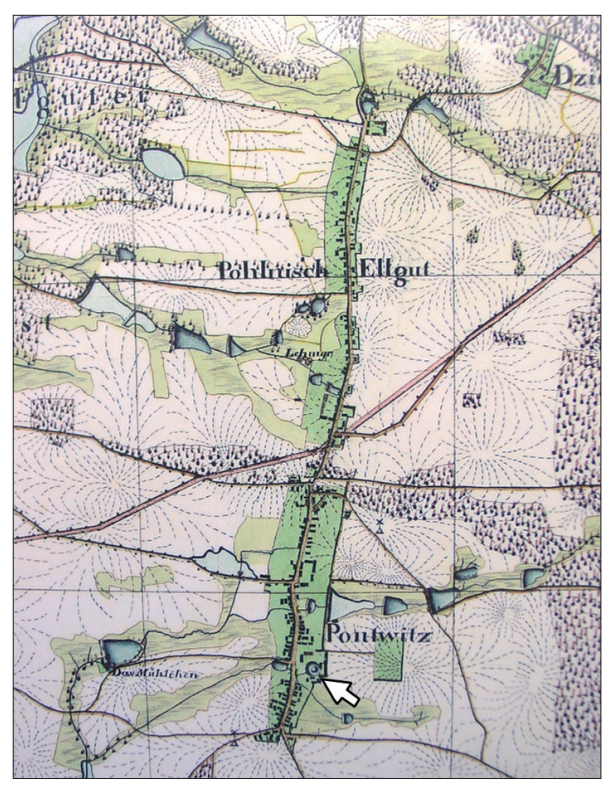

Fig. 6. Poniatowice village, Oleśnica district, according to the UrmeBtischblatt no. 2770 map, with the remains of a Late Medieval manor.

Source: Staatsbibliothek Berlin, Preußischer Kulturbesitz, sign. N 729 
the subject ${ }^{35}$, especially with the use of modern technologies (e.g.: ALS, LiDAR) providing new means of the analysis of various sources with the use of the Geographic Information System (GIS) ${ }^{36}$. The modern implements allow, among other things, for complex spatial analyses, as well as modelling and visualisation of gradual changes in settlement networks and in the use of terrain in varying time periods. Research on the newest settlement changes, especially those pertaining to lost and dying villages, might be utilised in the reconstruction of older settlement processes. Field research in particular, especially geomorphological cartography, is a important tool used to this purpose, allowing for the identification of current geomorphological processes in the landscape that have factored in either the preservation, or degradation of the visible in the landscape traits of the old settlements and economic activity within the last 40 to 100 years ${ }^{37}$. The link between a geomorphological process and the land form it produces provides the key to the understanding of cultural landscape transformations in the older time periods, which enables the reconstruction and interpretation of this landscape.

Another important source of information for researching historical settlement processes are folk and local names (Ger. Flurnamen), numerous in both the Urmesstischblätter and Messtischblätter maps. The importance of field names

\footnotetext{
35 R. Szmytkie, Nieistniejące wsie w Sudetach, in: Czas i przestrzeń w naukach geograficznych. Wybrane problemy geografii historycznej, red. M. Kulesza, tódź 2008, p. 225-242; A. Latocha, Zmiany krajobrazu wiejskiego w Sudetach w okresie powojennym, in: Polskie krajobrazy wiejskie dawne i wspótczesne, red. Z. Kuriata, Sosnowiec 2009 (Prace Komisji Krajobrazu Kulturowego PTG, 12), p. 130-139; eadem, Wyludnione wsie w Sudetach. I co dalej?, "Przegląd Geograficzny", 85 (3), 2013, p. 323-346. 36 J. Urbański, G/S w badaniach przyrodniczych, Gdańsk 2008.

37 A. Latocha, Contemporary Landscape of Depopulated Areas as a Mosaic of Relict and Active Landscape Features (Stofowe Mts Case Study), "The Problems of Landscape Ecology", 30, 2011, p. 309-316; eadem, Recovering the Lost Landscapes of Abandoned Villages in the Sudetes Mountains, Southwest Poland, in: Recovering Lost Landscapes, ed. V. Ivanišević et al., Belgrade, 2015, p. 45-56; eadem, Opuszczone wsie Ziemi Kłodzkiej - metodyka istan badań, in: Wieś zaginiona, p. 93-111.
}

in settlement studies was first noted by German researchers; the interwar period saw studies on field names led by Ernst Maetschke and Arthur Zobel, conducted on the behalf of the Silesian Historical Committee (Historische Kommission für Schlesien), with progress documented in the a series of issues titled Schlesischer Flurnamen-Sammler, where first topical studies on the subject were also published $^{38}$. Regretfully, the catalogue compiled as part of these studies was lost during World War II. The Silesian Historical Committee resumed its activity in 1951 in Germany, under the supervision of Arthur Zobel, who at the time issued an appeal to former inhabitants of Silesia to send in remembered toponyms together with feature outlines of towns and villages ${ }^{39}$. Polish researchers were also conducting studies on toponymy in post-war Silesia; a Polish-German catalogue of Silesian location names was compiled by means of search queries in archives. The gruelling work by a research team led by Stanisław Rospond produced numerous publications, including the Etymological Dictionary of Silesian Geographical Names, edited by Rospond and in press since $1970^{40}$. Toponymy and field names have long been used in settlement research ${ }^{41}$, and in the recent years they have prompted a discussion on the function of several medieval settlement complexes ${ }^{42}$.

38 "Schlesischer Flurnamen Sammler" (Breslau), 1-17/18, 1925-1942.

39 Arthur Zobel's scholarly heritage and the files on Silesian field names can currently be found in the archive of the Herder Institute for Historical Research on East Central Europe (Herder-Institut für historische 0stmitteleuropaforschung) in Marburg, Germany.

40 Stownik etymologiczny nazw geograficznych Śląska, t. 1, red. S. Rospond, Warszawa 1970; ibidem, t. 2-3, red. S. Rospond, H. Borek, Warszawa 1985-1986; ibidem, t. 4, red. H. Borek, Warszawa 1988; ibidem, t. 5-16, red. S. Sochacka, Opole 1991-2014.

41 T. Lalik, Stare Miasto w Łęczycy. Przemiany w okresie poprzedzającym Iokację - schyłek XII i początek XIII wieku, "Kwartalnik Historii Kultury Materialnej", 4 (4), 1956, p. 631-678.

42 D. Nowakowski, Alternatywna próba interpretacji funkcji zespołu osadniczego z Gostynia pod Głogowem w świetle danych archeologicznych i toponomastycznych, in: Miejsca pamięci: pradzieje, średniowiecze, wspótczesność, red. B. Gediga, A. Grossman, W. Piotrowski, BiskupinWrocław 2015 (Biskupińskie Prace Archeologiczne, 10), p. 499-525; 


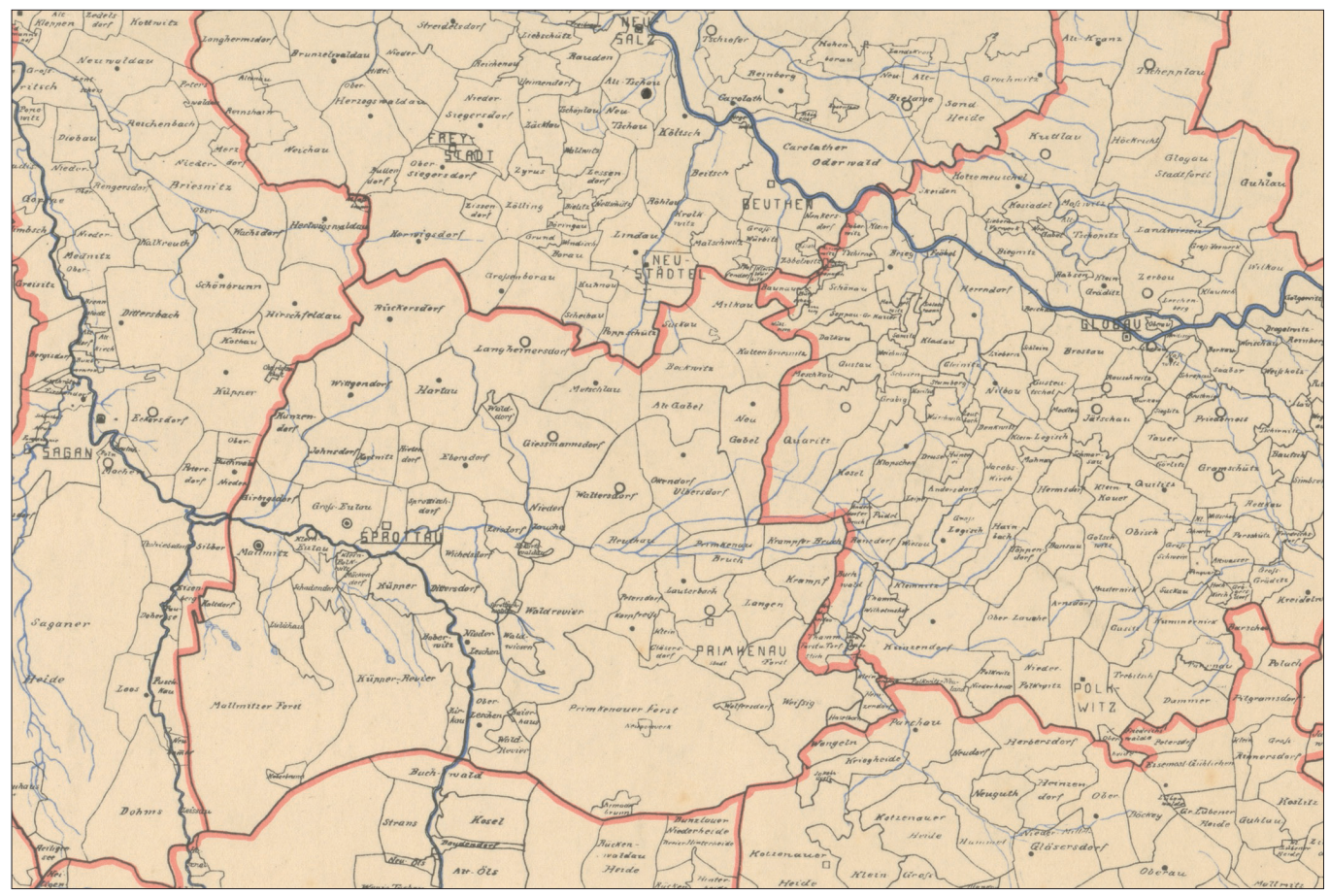

Fig. 7. A fragment of Max Hellmich reference map, with the so-called old settlement zone in the south-east and colonial villages in the central and western parts.

Source: Staatsbibliothek Berlin, Preußischer Kulturbesitz, sygn. N 15851

Maps drawn by means of compiling materials prove to be extremely useful in historical settlement research, and in turn become a source of information on their own merit. A good example here is an early $20^{\text {th }}$ century general map of Silesia (1:300 000) elaborated by Max Hellmich on the basis of the Messtischblätter maps. All existing villages in the province were marked on the map, together with their borders (Ger. Gemarkungsgrenzen). Comparison between the map and archaeological materials provides means of identification of areas in which Early Medieval settlement took place, as well as areas settled during the German colonial activity in the $13^{\text {th }}$ century (fig. 7). Settlement in the Early Middle Ages, placed roughly alongside the Oder river, is characterised by small

D. Adamska, Wokół zagadkowego Judenberg na Śląsku - problem średniowiecznych "osad żydowskich" w Europie Środkowej, in: Wieś zaginiona, p. 189-206. groupings of villages with Polish-sounding names, usually with a small acreage of farmland, and with irregularly shaped borders. On the other hand, areas settled in the $13^{\text {th }}$ and $14^{\text {th }}$ century are characterised by the emergence of sizeable colonial villages (of linear and/or market square structures) with German names, large acreage, regular village borders, and with Waldhufendorf ('forest') types of villages.

With the use of retrogressive methods, the compilation of various materials - archaeological, cartographic, and historical sources - allows for drawing reconstructive outlines for singular locations, representing their topography, settlement structures, route network, and land use (fig. 8). These plans do not serve the purpose of analysing the transformational dynamics of landscape, settlement, communication systems, or land use, but are rather an attempt at recreating 


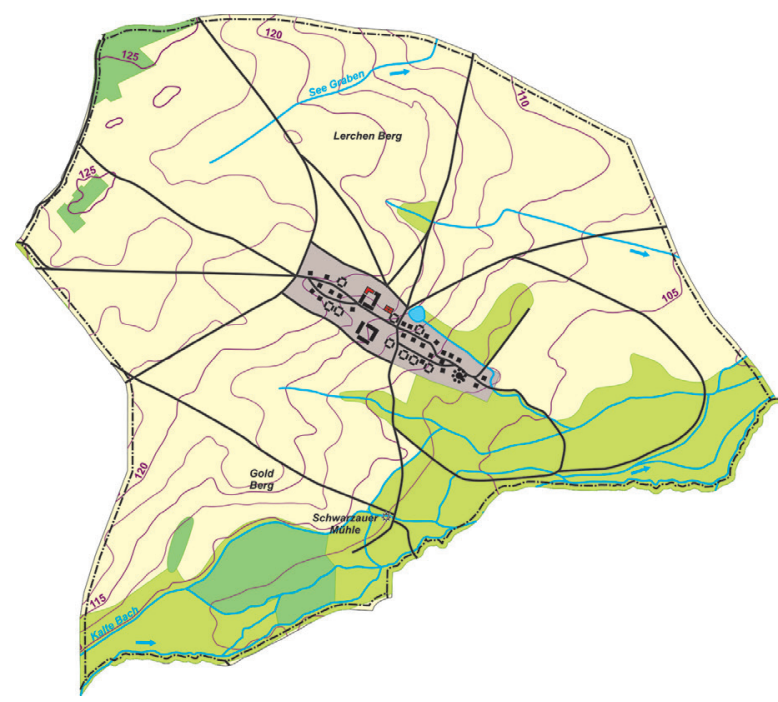

Fig. 8. Czerniec village, Lubin district. A reconstructed outline of the village. Source: "Stownik wsi śląskich", t. 1, tab. XIII:3

the earliest possible layout of the village and its surroundings. The outlines, prepared as specific thematic layers, provide new opportunities for the analysis of links between settlements and the natural landscape of a given area (settlements and their forms, field structures, communication systems). The aforementioned Geographical Information System (GIS) is an ideal tool for this sort of analysis, useful in both reconstruction and visualisation of spatial data, which can be used to protect and promote cultural heritage, including the cultural heritage of early settlements ${ }^{43}$.

There has been a decidedly positive change in the stance of state conservational bodies regarding the protection and research on rural settlements. Special protected areas, concentrated especially those of medieval origin, have been marked on the area zoning plans (Pol. miejscowe plany zagospodarowania przestrzennego) developed by the Regional Centres for Research and

43 I. Jażdżewska, Zastosowanie Systemów Informacji Geograficznej (GIS) w zachowaniu dziedzictwa kulturowego, in: Rola nauki w zachowaniu dziedzictwa kulturowego: wspótpraca między uczelniami wyższymi a muzeami, archiwami i stużbami konserwatorskimi na terenie regionu tódzkiego, red. B. Więcek, J. Perkowskie, Łódź 2010, p. 167-183.
Protection of Cultural Heritage (Pol. Regionalne Ośrodki Studiów i Ochrony Środowiska Kulturowego). Consequently, the last few years have seen various archaeological interventions at road and motorway construction sites, as well as, on a smaller scale, archaeological works accompanying rural infrastructure modernisation. The compiled data casts a new light on the pre-existing notions and verifies earlier theories on the range, development, and character of medieval settlement in Silesia.

In the context of the various sources and materials used in studying historical settlement processes, as well as the possible research methods explored in this article, the importance of interdisciplinary studies cannot be stressed enough, especially in the reconstruction of the earliest stages of the development of settlements and economy in a given area. The use of various complementary methods from various scientific fields - archaeological, historical, geographical, including cartographic and field research - allows for the best possible reconstruction of the cultural landscape of centuries past.

Translated by Paulina Wactawik 


\section{Bibliography}

Adamska D., Wokót zagadkowego Judenberg na Ślqsku - problem średniowiecznych "osad żydowskich w Europie Środkowej, in: Wieśzaginiona. Stan i perspektywy badań, red. P. Nocuń, A. Przybyła-Dunin, K. Fokt, Chorzów 2016, p. 189-206.

Adamska D., Nowakowski D., Bankau pod Gtogowem - zaginiona wieś w świetle źródet archeologicznych i pisanych, in: Z badań nad historia Ślaska i Europy w wiekach średnich, red. M. Goliński, S. Rosik, Wrocław 2013 (Scripta Historica Medievalia, 3), p. 123-139.

Bartosiewicz S., Istniejąca i projektowana zabudowa bydrotechniczna Odry - rys historyczny, in: Korytarz ekologiczny doliny Odry, red. W. Janowski, K. Świerkosz, Warszawa 1995, p. 66-75.

Ciok S., Rozwój osadnictwa na Dolnym Ślasku po II wojnie światowej. Tendencje $i$ kierunki zmian, Wrocław 1994 (Acta Universitatis Wratislaviensis. Studia Geograficzne, 61), p. 9-49.

Ciok S., Zmiany ludnościowe i osadnicze $w$ Sudetach, Wrocław 1995 (Acta Universitatis Wratislaviensis. Prace Instytutu Geograficznego. Seria B, 12), p. 51-64.

Figlus T., Wybrane aspekty zastosowania wielkoskalowych źródet kartograficznych $w$ badaniach morfogenetycznych wsi, "Biblioteka Polskiego Przeglądu Kartograficznego”, 3, 2012, p. 91-103.

Flis J., Terminy geograficzne, Warszawa 1999.

Fokt K., Późnośredniowieczne osadnictwo wiejskie na Dolnym Ślasku w świetle badań archeologicznych, Kraków 2012.

Fokt K., Legut-Pintal M., Zanikte wsie Wzgórz Strzelińskich: stan i perspektywy badań, in: Wieś zaginiona. Stan i perspektywy badań, red. P. Nocuń, A. Przybyła-Dunin, K. Fokt, Chorzów 2016, p. 113-145.

Gospodarka stawowa na Dolnym Ślasku w świetle materiatów zachowanych $w$ archiwach państwowych we Wroctawiu i w Legnicy 1447-1943, red. A. Drabiński, M. Janowski, Wrocław 1980.

Gringmuth-Dallmer E., Landesausbau und Wüstungsgeschehen, in: Mensch und Umwelt. Studien zu Siedlungsausgriff und Landesausbau in Ur-und Frühgeschichte, Hrsg. H. Brachmann, H.-J. Vogt, Berlin 1992, p. 209-217.

Jankuhn H., Einführung in die Siedlungsarchäologie, Berlin-New York 1977.

Jażdżewska I., Zastosowanie Systemów Informacji Geograficznej (GIS) w zachowaniu dziedzictwa kulturowego, in: Rola nauki w zachowaniu dziedzictwa kulturowego: wspótpraca między uczelniami wyższymi a muzeami, archiwami i stużbami konserwatorskimi na terenie regionu tódzkiego, red. B. Więcek, J. Perkowskie, Łódź 2010, p. 167-183.
Kajzer L., Wstęp do archeologii historycznej w Polsce, Łódź 1996.

Kara M., Najstarsze państwo Piastów - rezultat przetomu czy kontynuacji. Studium archeologiczne, Poznań 2009.

Kolenda J., Dawne projekty - nowe możliwości. Przyczynek do badań wczesnośredniowiecznej wsi, in: Cum gratia et amicitia. Studia $z$ dziejów osadnictwa dedykowane Pani Profesor Marcie Mtynarskiej-Kaletynowej z okazji 65-lecia dziatalności naukowej, red. D. Adamska, K. Chrzan, A. Pankiewicz, Wrocław 2017, p. 43-57.

Konias A., Kartografia topograficzna państwa i zaboru pruskiego od II potowy XVIII wieku do potowy XX wieku, Słupsk 2010.

Krenzlin A., Siedlungsformen und Siedlungsstrukturen in deutsch-slawischen Kontaktzonen (mit besonderer Berücksichtigung Brandenburgs und angrenzender Gebiete), "Germania Slavica”, 1, 1980, p. 239-274.

Lalik T., Stare Miasto w Eęczycy. Przemiany w okresie poprzedzajacym lokacje - schytek XII i początek XIII wieku, "Kwartalnik Historii Kultury Materialnej", 4 (4), 1956, p. 631-678.

Latocha A., Contemporary Landscape of Depopulated Areas as a Mosaic of Relict and Active Landscape Features (Stotowe Mts Case Study), "The Problems of Landscape Ecology”, 30, 2011, p. 309-316.

Latocha A., Opuszczone wsie Ziemi Ktodzkiej - metodyka i stan badań, in: Wieś zaginiona - stan i perspektywy badań, red. P. Nocuń, A. Przybyła-Dumin, K. Fokt, Chorzów 2016, p. 93-111.

Latocha A., Przemiany środowiska przyrodniczego w Sudetach Wschodnich $w$ warunkach antropopresji, Wrocław 2007 (Studia Geograficzne, 80).

Latocha A., Recovering the Lost Landscapes of Abandoned Villages in the Sudetes Mountains, Southwest Poland, in: Recovering Lost Landscapes, red. V. Ivanišević et al., Belgrade 2015, p. 45-56.

Latocha A., Śladami przesztości - czytanie krajobrazu kulturowego Ziemi Ktodzkiej, in: Krajobraz jako nośnik idei. Ujęcia analityczne, red. K. Kołodziejczyk, D. Chylińska, A. Zaręba, Wrocław 2014 (Studia Krajobrazowe, 4B), p. 159-172.

Latocha A., Wyludnione wsie w Sudetach. I co dalej?, "Przegląd Geograficzny", 85 (3), 2013, p. 323-346.

Latocha A., Zmiany krajobrazu wiejskiego $w$ Sudetach wokresie powojennym, in: Polskie krajobrazy wiejskie dawne i wspótczesne, red. Z. Kuriata, Sosnowiec 2009 (Prace Komisji Krajobrazu Kulturowego PTG, 12), p. 130-139.

Legut-Pintal M., Ślaski model melioratio terrae na przyktadzie ziemi nysko-otmuchowskiej i Pogórza Kaczawskiego, in: Cum gratia et amicitia. Studia zdziejów osadnictwa dedykowane Pani Profesor Marcie 
Mtynarskiej-Kaletynowej z okazji 65-lecia dziatalności naukowej, red. D. Adamska, K. Chrzan, A. Pankiewicz, Wrocław 2017, p. 179-194.

Liber fundationis Episcopatus Vratislaviensis, Hrsg. H. Markgraf, J.W. Schulte, Breslau 1889 (Codex Dipolmaticus Silesiae, 14).

Miszewska B., Zmiany zaludnienia Sudetów w okresie powojennym, "Czasopismo Geograficzne", 60 (2), 1989 , p. 135-145.

Młynarska-Kaletynowa M., W sprawie polskich badań nad osadnictwem średniowiecznym, "Studia z Dziejów Osadnictwa”, 6, p. 82-102.

Moździoch S., Castrum munitissimum Bytom. Dzieje lokalnego grodu jako archeologiczny przyczynek do badań nad początkami państwa polskiego, Warszawa 2002.

Moździoch S., Organizacja gospodarcza państwa wczesnopiastowskiego na Ślasku. Studium archeologiczne, Wrocław-Warszawa-Kraków 1990.

Moździoch S., Refleksje na temat stanu wiedzy archeologicznej o ślaskim wczesnym średniowieczu, in: Stan $i$ potrzeby badań nad wczesnym średniowieczem $w$ Polsce - 15 lat później, red. W. Chudziak, S. Moździoch, Toruń-Wrocław-Warszawa 2006, p. 189-206.

Nowakowski D., Alternatywna próba interpretacji funkcji zespotu osadniczego z Gostynia pod Gtogowem $w$ świetle danych archeologicznych $i$ toponomastycznych, in: Miejsca pamięci: pradzieje, średniowiecze, współczesność, red. B. Gediga, A. Grossman, W. Piotrowski, Biskupin-Wrocław 2015 (Biskupińskie Prace Archeologiczne, 10), p. 499-525.

Piekalski J., Od Kolonii do Krakowa. Przemiana topografii wczesnych miast, Wrocław 1999.

Plewniak W., Zmiany w środowisku geograficznym doliny Dzikiej Orlicy w Górach Bystrzyckich wywotane wyludnianiem wsi, Wrocław 1978 (Acta Universitatis Wratislaviensis. Prace Instytutu Geograficznego. Seria B, 2), p. 97-109.

Sawicka B., Zmiany $w$ zaludnieniu $i$ użtkowaniu gruntów wsi górskich na wybranych obszarach przygranicznych Sudetów Ktodzkich, Wrocław 1983 (Acta Universitatis Wratislaviensis. Studia Geograficzne, 32), p. 23-30.
"Schlesischer Flurnamen Sammler" (Breslau), 1-17/18, 1925-1942.

Schulze H.K., Die Besiedlung der Mark Brandenburg im hohen und späten Mittelalter, "Jahrbuch für die Geschichte Mittel- und Ostdeutschland”, 28, 1979, p. 42-178.

Stownik etymologiczny nazw geograficznych Ślaska, t. 1, red. S. Rospond, Warszawa 1970.

Stownik etymologiczny nazw geograficznych Ślaska, t. 2-3, red. S. Rospond, H. Borek, Warszawa 1985-1986.

Stownik etymologiczny nazw geograficznych Ślaska, t. 4, red. H. Borek, Warszawa 1988.

Stownik etymologiczny nazw geograficznych Ślaska, t. 5-16, red. S. Sochacka, Opole 1991-2014.

Stownik wsi ślaskich w średniowieczu, t. 1: Powiat lubiński, oprac. D. Adamska et al., Wrocław 2014.

Sobik M., Kasprzak M., Przyrodnicze uwarunkowania klesk elementarnych na obszarze Dolnego Ślaska, in: Kleski żywiotowe $w$ postaci zdarzeń powodziowych $i$ ich pochodnych na Ślasku od XIV do XX w., red. E. Kościk, B. Konopska, Warszawa 2016, p. 29-62. Starkel L., Paleogeografia holocenu, Warszawa 1977.

Szmytkie R., Nieistniejące wsie w Sudetach, in: Czas i przestrzeń $w$ naukach geograficznych. Wybrane problemy geografii historycznej, red. M. Kulesza, Łódź 2008, p. 225-242.

Szulc H.Z., Morfogeneza osiedli wiejskich w Polsce, Wrocław 1995 (Prace Geograficzne, 163).

Teisseyre A., Mady rzek sudeckich. Część I: Ogólna charakterystyka środowiskowa (na przyktadzie zlewni górnego Bobru), "Geologia Sudetica”, 20 (1), 1985, p. 113-195.

Tyszkiewicz J., Geografia historyczna Polski w średniowieczu, Warszawa 2003.

Urbański J., GIS w badaniach przyrodniczych, Gdańsk 2008.

Wspótczesne przemiany rzeźby Polski, red. L. Starkel et al., Kraków 2008.

Zagożdżon A., Wybrane problemy ludnościowe Sudetów na tle rozwoju regionalnego, Warszawa 1990 (Studia KPZK, 96), p. 95-111. 


\section{Summary}

The article presents several insights on the sources and methods used in the research of medieval settlement processes using the example of Silesia region. The number and variety of sources (archaeological, written, cartographic) used in the analysis of settlement processes makes it a subject of interest for researchers representing various fields, such as archaeology, history, and historical geography, which have already got their own established research methods. Growing interest in the topic of Late Medieval settlement has prompted an influx of studies on the topic; these are most often interdisciplinary in nature, resulting in articles and monographs published within the last few years, while integrated cooperative studies employing representatives of several different fields are more rare. The works on a dictionary of medieval villages in Silesia, which employed archaeologists, historians, a geographer, and a historical cartographer. The sources described in the article provide specific (though also limited) information on past settlement processes. Archaeological materials, mostly acquired by means of field survey, though by nature chronologi- cally imprecise, provide data on everyday life of urban and rural residents, their production and the economy (eg.: extraction and processing of raw materials); written sources are important in identifying key information, such as the identification of settlement initiators or the analysis of land ownership relations; likewise, concurrent pieces of mass documentation which enable statistical analysis and comparative analysis, such as land books, inventories of goods, and ledgers, are of fundamental importance to research. Maps of appropriate scale (usually dating to the $18^{\text {th }}$ or $19^{\text {th }}$ century) remain the basic source of information in the geographic analysis of settlement processes. The modern character of the maps means that retrogressive methods are most useful in the reconstruction of the late medieval settlement networks. They help recreate elements of historical natural landscape, as well as traces of settlements and economic activity. Retrogressive methods, successfully employed in historical geography, is based on the assumption that it is possible to make conclusions about an earlier reality based on sources from a later period.

Keywords: historical geography, settlement archeology, medieval archeology, Silesia, medieval villages

Agnieszka Latocha - assistant professor at the Institute of Geography and Regional Development at the University of Wrocław. Her scientific interests focus on long-term human-environment relationships, changes in the cultural landscape, and the permanence of anthropogenic changes in depopulated areas (e-mail: agnieszka.latocha@uwr.edu.pl)

Dominik Nowakowski - reseach and technical assistant at the Centre for Late Antique and Early Medieval Studies at the Institute of Archaeology and Ethnology of the Polish Academy of Sciences in Wrocław. The author's research interests include issues concerning settlement processes, as well as defensive and residential structures in medieval Silesia (e-mail: dominiknowakowski74@gmail.com) 